\title{
Can the Treaty State Aid Regime Come to the Rescue of Climate Change?
}

Energy subsidies worldwide were projected at US\$5.3 trillion in 2015 , or $6.5 \%$ of global GDP ${ }^{1}$ (that is equivalent to \$10 million per minute). Within the European Union, public support (not including transport) is estimated at over $€_{200}$ billion per annum. This level of support is mainly due to the significant differences in tax rates between different fossil fuels. ${ }^{2}$

Despite numerous international commitments to reduce this level of subsidisation, little appears to have been achieved. In 2014, the Council of the European Union launched an ambitious Climate and Energy Policy Framework, committing the EU to reduce greenhouse gas emissions by $40 \%$ by 2030 , to promote renewable energy so that at least $27 \%$ of all energy produced in Europe is sourced from renewable sources and embrace increased energy efficiency (to achieve a 30\% improvement compared to 1990). ${ }^{3}$

The subsequent launch of the 'Clean Energy Transition' and an extensive package of draft legislation on 30 November 2016 are intended to be major steps towards a low carbon economy, so that by 2050 Europe's reliance on fossil fuels (many of which are imported) will be substantially reduced if not eradicated. Accompanying initiatives on lowering harmful emissions in the European transport sector have been less ambitious. Under the terms of the current 2009 Renewable Energy Directive 2009/28 (RED), EU Member States are required to source $10 \%$ of transport energy from renewable sources, mainly biofuels, by $2020 .{ }^{4}$ Binding national targets will disappear after 2020 , however, to be replaced by a binding EU-wide target.

The recently published recast of the RED ${ }^{5}$ envisages continued State support to RES production, in line with the EEAG of 2014. The State aid regime will have an important role to play in ensuring that such support takes the form of 'good aid'. But far more will be required of the Treaty toolbox in the Clean Energy Transition, and especially in the transport sector. As the Commission has proclaimed "The ambition is clear: by mid- century, greenhouse gas emissions from transport will need to be at least 60\% lower than in 1990 and be firmly on the path towards zero". ${ }^{\prime}$ Although progress has undoubtedly been made in reducing emissions in the power sector, greenhouse gas emissions from the transport sector have grown for the first time since 2007, as data released in 2016 by the European Environment Agency (EEA) has confirmed. Transport has now become the single biggest emitter of greenhouse gases in Europe. Yet certain sectors such as aviation are chronically undertaxed. There is no VAT on airline tick-

D Coady, I Parry, L Sears and B Shang, 'How Large Are Global Energy Subsidies?'(May 2015) IMF Working Paper, WP/15/105.

2 Ecofys, 'Subsidies and the Costs of Energy' (2014) Study for the European Commission, available at <https://ec.europa.eu/energy/sites/ener/ files/documents/ECOFYS\%202014\%20Subsidies\%20and\%20costs\%20of\%20EU\%20energy_11_Nov.pdf> Last accessed on 10 March 2017.

3 European Council, Climate and Energy Policy Framework-Conclusions (24 October 2014), available at <http://www.consilium.europa.eu/ uedocs/cms_data/docs/pressdata/en/ec/145397.pdf> Last accessed on 10 March 2017.

4 The Fuel Quality Directive (FQD) 2014/94/EU has a carbon intensity reduction target of 6\% by 2020.

5 European Commission, Proposal for a Directive on the promotion of the use of energy from renewable sources (recast) COM (2016) 767 final of 30 November 2016; Corrigendum of 23 February 2017 available at <http://eur-lex.europa.eu/legal-content/EN/TXT/?uri=CELEX: 52016PC0767R\%2801\%29> Last accessed on 14 March 2017.

6 European Commission, A European Strategy for Low-Emission Mobility (20 July 2016), available at <https://ec.europa.eu/transparency/regdoc/ rep/1/2016/EN/1-2016-501-EN-F1-1.PDF> Last accessed on 1 March 2017. 
ets, no kerosene tax, and many airports receive generous subsidies. Not only does the sector not pay its real costs but it enjoys huge transfers from governments. ${ }^{7}$

Given the omnipresence of support for fossil fuels, what role could and should the Treaty State aid regime play in this ambitious programme for transition? Can the State aid regime compensate for the failure of Member States to agree on what many would argue are more effective instruments such as a carbon tax - for stimulating the phase out of fossil fuels? State aid to the energy sector is now the second largest category of aid in the Member States, according to the last available Commission State Aid Scoreboard. Much of the reported aid is targeted at the promotion of renewable energy (especially solar and wind). This type of aid is invariably deemed to be compatible aid. Even so, it is but a fraction of the public support for fossil fuels across the EU.

Favourable tax treatment is an important form of aid especially for the producers as well as consumers of fossil fuels. Yet despite the Treaty commitment to making the polluter pay as the contributions to this special issue confirm, the application of Article 107 TFEU to preferential tax treatment for fossil fuels has not contributed to the phasing out of national support mechanisms to any meaningful degree. Nor is the current EEAG of 2014 necessarily 'fit for purpose'. The guidelines are criticised by many commentators as incoherent if not inconsistent (particularly with regard to support for biofuels).

Could a concerted campaign on fossil fuel support become the next chapter in the Commission's crusade against unfair taxation? Given the failure to date of Member States to agree on alternative measures, the Treaty State aid regime may once again be called on to play the knight in shining armour in the increasingly urgent fight for climate change and in the realisation of the 'Clean Energy Transition'. Ultimately, unfair taxation and clean energy transitions come down to the same political hot potato - a fundamental re-distribution of wealth. The coming months will no doubt demonstrate whether either or both of these crusades are too hot to handle'.

Leigh Hancher

7 L Chancel and T Piketty, Carbon and inequality: From Kyoto to Paris. Trends in the global inequality of carbon emissions (1998-2013) \& Prospects for an equitable adaptation fund, (Paris: Paris School of Economics 2015). 